\author{
JKTP Vol 3 No (2) Mei (2020): 166-177 \\ DOI: $10.17977 /$ um038v3i22020p166
}

JKTP Jurnal Kajian Teknologi Pendidikan

http://journal2.um.ac.id/index.php/jktp/index

\title{
PEDAGOGICAL KNOWLEDGE (PK) GURU DALAM PENGEMBANGAN DAN IMPLEMENTASI RENCANA PEMBELAJARAN
}

\author{
Pipit Novita Candra, Yerry Soepriyanto, Henry Praherdhiono \\ Jurusan Teknologi Pendidikan, Fakultas Ilmu Pendidikan, Universitas Negeri Malang \\ Jalan Semarang 5 Malang 65145-0341-5747001 \\ Email: yerry.soepriyanto.fip@um.ac.id
}

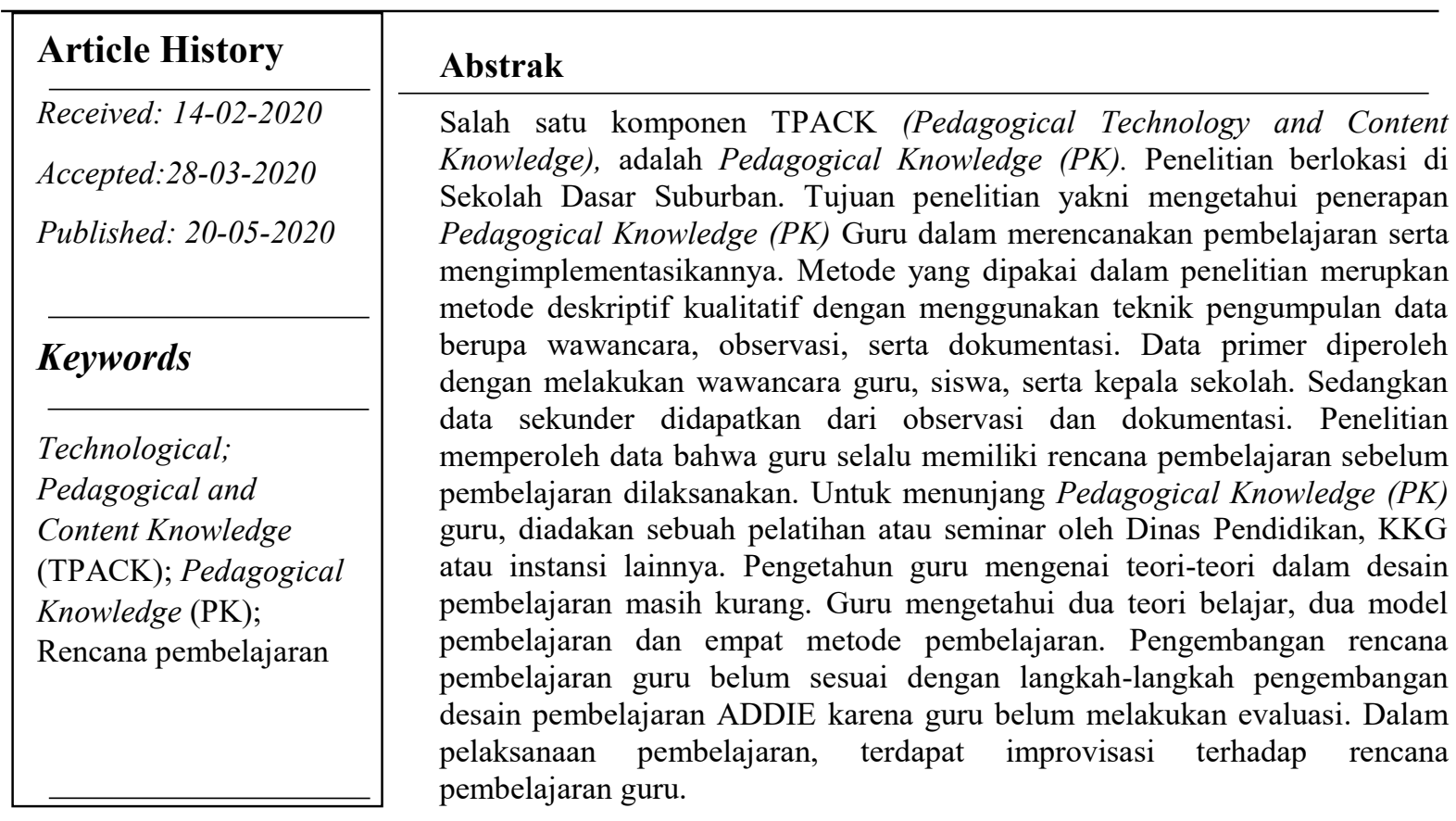

\footnotetext{
Abstract

One component of TPACK (Pedagogical Technology and Content Knowledge), is Pedagogical Knowledge (PK). Research location in Suburban Elementary School. The research objective is to study the application of Teacher's Pedagogical Knowledge (PK) in learning and implementing it. The method used in this research is a qualitative descriptive method using data collection techniques using interviews, observation, and documentation. Primary data were obtained by interviewing teachers, students and principals. While secondary data obtained from observation and documentation. Research Receiving data as a teacher always has a learning plan before learning is done. To support teacher's Pedagogical Knowledge (PK), conduct training or seminars by the Education Office, KKG or other institutions. The teacher's knowledge of theories in learning design is still lacking. The teacher learns two learning theories, two learning models and four learning methods. The development of teacher learning plans is not appropiate in the steps of
} 
developing ADDIE learning designs. In the implementation of learning, improvisation is made for teacher learning plans. 


\section{PENDAHULUAN}

Pembelajaran merupakan dasar dari terciptanya sebuah pendidikan. Pembelajaran terjadi melalui interaksi guru dengan siswa serta sumber belajar pada satu lingkungan belajar untuk membelajarkan siswa. Dalam pembelajaran terjadi proses belajar yang dirancang, dilaksanakan, serta dievaluasi agar pembelajaran sesuai dengan tujuan yang ditetapkan.

Pembelajaran di sekolah dasar berperan sebagai penempatan dasar keilmuan serta membantu pengoptimalan perkembangan anak lewat pembelajaran menarik dengan bimbingan guru. Oleh sebab itu, guru memiliki peran penting saat pelaksanaan pembelajaran untuk menentukan keberhasilan peserta didik (Sudjana, 2004). Tugas guru bukan hanya mendidik, guru perlu ikut andil untuk merancang pembelajaran efektif serta efisien. Karena kesuksesan pembelajaran dimulai dari perencanaan pembelajaran yang dibuat guru (Zendrato, 2016). Ini sesuai tujuan diterapkannya Kurikulum 2013, yakni menuntut guru menjadi pribadi kreatif, produktif dan inovatif serta dapat menciptakan pembelajaran yang demokratis. Saat proses pembelajaran demokratis, siswa dijadikan subjek pembelajaran (Arends, 2008). Guru diharuskan memiliki banyak kemampuan agar dapat menciptkaan pembelajaran efektif serta efisien.

Beberapa peneliti telah melakukan penelitian mengenai Pedagogical Knowledge (PK) guru. Dalam penelitian (Feladi \& Puspitasari, n.d.) yang berjudul Analisis Profil TPACK Guru TIK SMA di Kecamatan Pontianak, menghasilkan data bahwa guru sangat menguasai dalam pembuatan perangkat pembelajaran. Guru juga sering membuat perangkat pembelajaran seperti RPP, karena guru merasa sangat mudah jika dalam penyampaian materi disajikan atau disusun terlebih dahulu. Pedagogical Knowledge (PK) yang diteliti yakni pengetahuan guru dalam mengembangkan perangkat pembelajaran berupa RPP, pengetahuan guru tentang model pembelajaran, metode, teknik penilaian, serta pengelolaan kelas. Dalam penelitian (Hidayati, Setyosari, \& Soepriyanto, 2019) tentang Persepsi TPACK Guru SMA Berdasarkan Jender, diperoleh hasil bahwa Pedagogical Knowledge (PK) tergolong dalam kategori tinggi. Pedagogical Knowledge (PK) yang diteliti yakni penilaian terhadap siswa, pendekatan pengajaran, manajemen kelas, penyesuaian gaya belajar dengan siswa. Dalam penelitian (Iftitah, 2017) tentang Profil TPACK Guru Ilmu Pengetahuan Alam Jenjang SMP diperoleh data bahwa Pedagogical Knowledge (PK) yang dimiliki guru yakni, 1 teori belajar, 1 pendekatan pembelajaran, 3 strategi pembelajaran, 6 metode pembelajaran, 9 teknik mengajar, 4 prinsip-prinsip pembelajaran, 5 jenis evaluasi hasil belajar, 10 karakteristik peserta didik, namun belum memiliki pegetahuan dalam evaluasi pembelajaran. Selain itu, menurut (Kalu, 2016) kompetensi pedagogik guru Sekolah Dasar yang tersertifikasi pada pembelajaran sains berada pada kategori baik.

Penelitian oleh (Feladi \& Puspitasari, n.d.; Hidayati et al., 2019; Iftitah, 2017; Kalu, 2016) mendapatkan hasil bahwa Pedagogical Knowledge (PK) guru dalam keadaan baik. Selain penelitian tersebut, terdapat penelitian oleh (Sumiarsi, 2015) mengenai Analisis Kompetensi Pedagogik dan Pengembangan Pembelajaran Guru SD Negeri 041 Tarakan. Berdasarkan observasi awal dalam penelitian ini menemukan bahwa masih adanya guru yang melakukan pembelajaran secara monoton, masih bertindak layaknya penguasa kelas, serta tidak memberikan ruang yang jelas dan konkret bagi perkembangan anak didik. Guru juga hanya bercerita tanpa memberikan stimulus bagi anak agar anak memberi respon, serta masih banyak kegiatan pembelajaran yang bersifat konvensional dan belum mengarah pada pembelajaran aktif dan dialogis, seperti yang tertera dalam standar kompetensi pedagogik dalam undang-undang. Berdasarkan hasil penelitian, Pedagogical Knowledge (PK) yang dimiliki guru khususnya komponen pengembangan dan implementasi rencana pembelajaran masih belum optimal. Karena pembelajaran yang belum efektif dan efisien mencerminkan pengembangan dan implementasi rencana pembelajaran yang belum optimal. Selain itu, menurut (Bararah, 2017), pembelajaran hanya akan tercapai asalkan dilandaskan pada perencanaan pembelajaran yang telah siap dan pembelajaran dalam keadaan sehat.

Dari penelitian (Feladi \& Puspitasari, n.d.; Hidayati et al., 2019; Iftitah, 2017; Sumiarsi, 2015) terdapat ketidaksesuaian antara Pedagogical Knowledge (PK) guru dengan pengimplementasiannya, sehingga perlu adanya penelitian mengenai pengembangan dan implementasi rencana pembelajaran. Berdasarkan pemaparan tersebut, penelitian bertujuan untuk melihat bagaimana guru Sekolah Dasar 
Suburban (wilayah yang berada pada pinggiran perkotaan) mengembangkan dan mengimplementasikan rencana pembelajaran.

\section{Technological Pedagogical and Content Knowledge (TPACK)}

Pendidikan saat ini sering disebut sebagai pendidikan 4.0, para ahli pendidikan menggambarkannya sebagai cara mengimplementasikan teknologi cyber ke dalam pembelajaran. Menurut (Sintawati \& Indriani, 2019), pendidikan 4.0 menuntut guru menguasai teknologi untuk diintegrasikan dalam proses pembelajaran. Pengintegrasian teknologi ke dalam pembelajaran terdapat pada kerangka kerja TPACK. TPACK (Technological Pedagogical and Content Knowledge) menggambarkan kerangka kerja guru yang memadukan pengetahuan teknologi, pedagogik, dan konten dalam sebuah pembelajaran. Istilah TPACK pertama kali muncul dengan melalui jurnal penelitian Mishra dan Koehler tahun 2006 berjudul Technological Pedagogical Content Knowledge : A Framework for Teacher Knowledge. TPACK memiliki tiga komponen dasar dalam pengetahuan yakni pengetahuan teknologi, pedagogi, serta konten. Kerangka kerja ini mengharuskan guru dapat mengintegrasikan tiga komponen dalam TPACK yakni pedagogi, konten, dan teknologi. Menurut (Koehler \& Mishra, 2009) untuk menciptakan pembelajaran berkualitas memerlukan pemahaman kompleks yang saling berhubungan antara tiga sumber utama pengetahuan yakni teknologi, pedagogi dan konten, serta bagaimana ketiga komponen tersebut diterapkan sesuai dengan konteksnya. Terdapat tujuh domain pengetahuan dalam Pedagogical and Content Knowledge (TPACK) menurut (Koehler \& Mishra, 2009) seperti gambar 1:

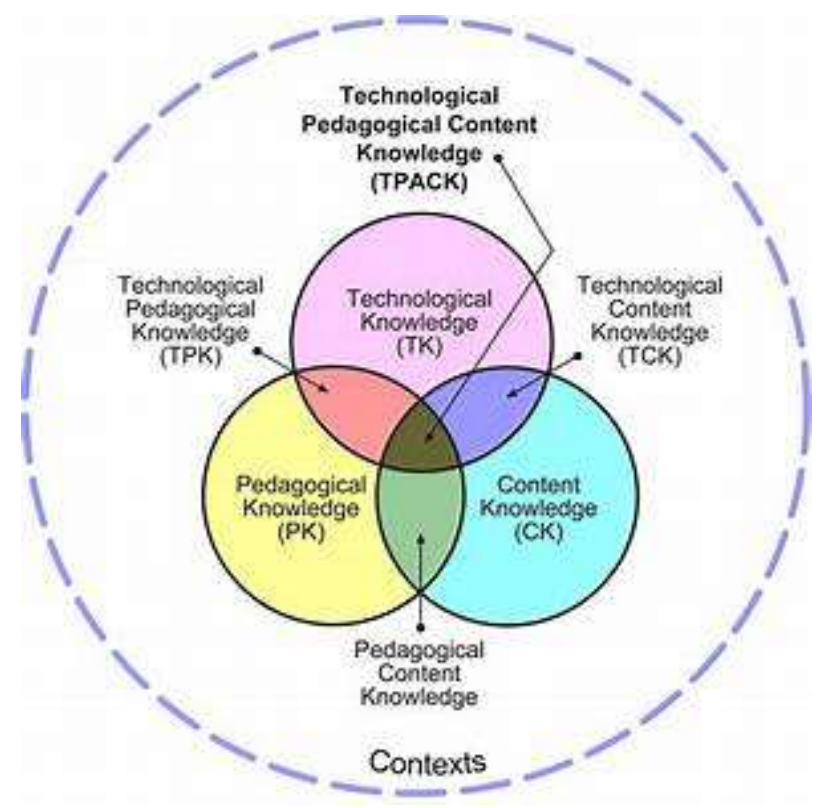

Gambar 1. Tujuh Domain Pengetahuan TPACK (Koehler \& Mishra, 2009)

Karena pentingnya Technological Pedagogical and Content Knowledge (TPACK) pada dunia pendidikan, sudah banyak penelitian oleh peneliti bidang pendidikan. (Archambault \& Crippen, 2009) telah melakukan penelitian mengenai korelasi diantara tiga komponen utama TPACK. Penelitian ini mengasilkan data bahwa terdapat korelasi kecil antara teknologi dan pedagogi serta teknologi dan konten, namun terdapat korelasi besar antara pedagogi dan konten. Selain itu, (Suharwoto \& Niess, 2001) telah melakukan penelitian mengenai cara meningkatkan TPACK guru preservice oleh. Penelitian lain telah dilakukan oleh (Rachmatulloh, Fitriah, \& Lestari, 2015) mendapatkan hasil bahwa tingkat kemampuan TPACK guru tidak berbanding lurus dengan lamanya pengalaman mengajar.

\section{Pedagogical Knowledge (PK)}

Pedagogical Knowledge (PK) sering kali disebut sebagai kompetensi pedagogik. Pedagogik berasal kata paedos berarti anak dan agogos berarti membimbing. Lalu terjadi pergantian istilah dari paedagogos menjadi pedagog artinya pendidik. Setelah itu terbentuk istilah paedagogiek atau pedagogik yang memiliki arti ilmu pendidikan anak atau ilmu mendidik anak. 
Istilah pedagogik berkaitan dengan guru atau pendidik. Seorang guru harus memiliki berbagai macam pengetahuan untuk menunjang dalam proses pembelajaran. Pedagogical Knowledge (PK) menurut (Mishra \& Koehler, 2006) yakni pengetahuan yang mendalam tentang proses dan praktik atau metode pengajaran dan pembelajaran yang mencakup tujuan pendidikan keseluruhan, nilai-nilai dan tujuan. Sedangkan pedagogical Knowledge (PK) menurut (Shulman, 1987) digambarkan sebagai "Prinsip dan strategi luas untuk manajemen kelas dan organisasi yang tampaknya melampaui materi pelajaran". Dari pernyataan diatas, Pedagogical Knowledge (PK) adalah pengetahuan mendalam mengenai cara mengajar guru di dalam kelas atau ilmu dan seni mengajar anak untuk mencapai tujuan pembelajaran, sehingga pengelolaan pembelajaran dapat dilakukan dengan baik. Menurut (Cox \& Graham, 2009) Pedagogical Knowledge dibagi menjadi 2 yakni pedagogi spesifik yakni pedagogi yang hanya bisa dipakai oleh konten-konten tertentu dan pedagogi umum yang bisa dipakai oleh berbagai konten atau materi pembelajaran.

\section{Komponen Pedagogical Knowledge (PK)}

Terdapat beberapa komponen Pedagogical Knowledge (PK) menurut (Chai, Koh, \& Tsai, 2010) yaitu 1) penyesuaian gaya mengajar dengan pelajar yang berbeda, 2) penyesuaian pengajaran berdasarkan apa yang dipahami atau tidak dipahami siswa, 3) menggunakan berbagai pendekatan pengajaran di ruang kelas (pengajaran kolaboratif, instruksi langsung, pembelajaran inkuiri, dl1), 4) guru tahu bagaimana menilai kinerja siswa di kelas, 5) pengelolaan kelas. Sedangkan (Schmidt et al., 2009), menyatakan bahwa Pedagogical Knowledge (PK) merupakan rangkaian proses mengajar yang melibatkan metode termasuk pengetahuan pengelolaan kelas, memberikan penilaian, mengembangkan rencana pelaksanaan pembelajaran (RPP) dan proses pembelajaran.

Menurut (Mishra \& Koehler, 2006) Pedagogical Knowledge (PK) merupakan bentuk pengetahuan umum yang terlibat dalam semua masalah pembelajaran siswa, manajemen kelas, pengembangan dan implementasi rencana pembelajaran, serta evaluasi pembelajaran. Guru harus mampu mengembangkan dan mengimplementasikan rencana pembelajaran, hal ini sesuai dengan pendapat (Feladi \& Puspitasari, n.d.) bahwa dengan penggunaan perangkat pembelajaran seperti RPP (rencana pelaksanaan pembelajaran) guru akan lebih terbantu dalam pelaksanaan pembelajaran.

Rencana pembelajaran yang dibuat oleh guru dapat digunakan untuk jangka waktu satu pertemuan bahkan bisa lebih. Rencana pembelajaran dikembangkan dari standar kompetensi agar dapat mencapai kompetensi dasar serta tujuan pembelajaran. (Joseph \& Leonard, 1988) berpendapat bahwa mengajar tanpa persiapan tertulis akan menghasilkan ketidakefektifan pembelajaran di dalam kelas karena guru tidak memikirkan secara detail apa dan bagaimana proses pembelajaran terjadi. Untuk menunjang kemampuan guru dalam mengembangkan rencana pembelajaran, diperlukan pengetahuan mengenai teori belajar, model, strategi, metode pembelajaran. Kemampuan dalam pemilihan teori belajar, model, strategi, metode pembelajaran dapat menentukan pembelajaran seperti apa yang ingin diciptakan oleh guru.

Pembuatan rencana pembelajaran dapat mengacu pada pengembangan desain pembelajaran ADDIE (Branch, 2009). Tahapan pengembangan dari model ADDIE yakni Analysis (analisa), dilanjut dengan Design (perancangan), lalu Development (pengembangan), kemudian Implementation (implementasi), dan terakhir Evaluation (evaluasi). Analisis merupakan proses untuk menggambarkan apa yang akan dipelajari peserta didik. Dalam tahap analisis, perlu dilakukan analisis kebutuhan dan kinerja. Hasil analisis harus berupa identifikasi kesenjangan, karakteristik siswa, identifikasi kebutuhan, serta analisis tugas berdasarkan kebutuhan. Tahap desain dimulai dengan menentukan tujuan pembelajaran, merancang skenario pembelajaran, perangkat pembelajaran, materi pembelajaran, serta alat untuk mengevaluasi hasil belajar. Tahap pengembangan berisikan kegiatan merealisasikan rancangan produk menjadi produk yang siap diterapkan. Dalam tahap implementasi, rencana pembelajaran yang telah selesai dikembangkan kemudian diterpkan di kelas. Tahap yang terakhir yakni tahap evaluasi. Ditahap ini dilakukan dua bentuk evaluasi yitu evaluasi formatif dan sumatif. Evaluasi formatif dilakukan tiap akhir pertemuan, sedangkan evaluasi sumatif dilakukan setelah berakhirnya seluruh kegiatan dalam satu semester. Evaluasi sumatif mengukur ketercapaian tujuan pembelajaran serta kompetensi akhir mata pelajaran. Hasil evaluasi berfungsi sebagai feedback untuk guru. Jika 
terdapat kebutuhan yang belum terpenuhi oleh rencana pembelajaran yang dibuat dan implementasikan, maka harus dilakukan revisi sesuai hasil evaluasi.

Dalam proses pembelajaran, guru diharuskan mampu mengimplementasikan rencana pembelajaran yang telah disusun sebelumnya. Tujuannya adalah untuk menghindari ketidaksesuaian antara tujuan yang ingin diperoleh dengan pelaksanaan pembelajaran. Guru harus bisa mengimplementasikan teori belajar, model, strategi, metode yang telah dipilih sebagai bentuk pengimplementasian rencana pembelajaran. Dalam pembelajaran, guru diharuskan melakukan penyesuaian dengan siswa terlebih dahulu. Tujuannya adalah membuat siswa lebih mudah paham mengenai materi yang disampaikan.

Teori belajar sangatlah penting bagi guru, ini sesuai dengan (Mishra \& Koehler, 2006) yang menyatakan bahwa Pedagogical Knowledge (PK) membutuhkan pemahaman tentang teori belajar. Teori belajar lebih menekankan terhadap bagaimana seharusnya seseorang dapat belajar. Terdapat banyak teori belajar sampai saat ini, namun beberapa sumber telah mengelompokkannya menjadi 4 aliran yakni, behavioristik, konstruktivistik, kognitivistik dan humanistik.

Model pembelajaran bisa diartikan sebagai desain atau pola yang dijadikan pedoman dalam pelaksanaan pembelajaran. Model pembelajaran menggambarkan sebuah pola interaksi guru dan siswa di kelas dengan adanya strategi, metode, teknik yang digunakan saat pelaksanaan pembelajaran. Strategi pembelajaran menggambarkan sebuah kumpulan kegiatan yang berkaitan dengan manajemen siswa, lingkungan belajar, dan assesment. Strategi pembelajaran mengacu pada sebuah rencana untuk mencapai suatu tujuan pembelajaran. Jika strategi pembelajaran adalah sebuah perencanaan, maka metode pembelajaran yakni cara untuk mencapai strategi. Contoh dari metode pembelajaran adalah diskusi, ceramah, sosiodrama, demostransi dll.

\section{METODE}

Metode yang dipakai dalam penelitian ini merupakan kualitatif deskriptif. Penelitian bertujuan untuk mengetahui penerapan Pedagogical Knowledge (PK) guru dalam pengembangan rencana pembelajaran dan implementasinya. Sumber data dalam penelitian diambil dengan teknik purposif sampling untuk memperoleh fokus penelitians dari setiap sebjek penelitian. Subjek penelitian merupakan guru wali kelas 5, kepala sekolah, serta siswa kelas 5. Penelitian dilakukan di Sekolah Dasar Suburban.

\section{Instrumen Penelitian dan Prosedur Pengumpulan Data}

Tiga prosedur pengumpulan data yang dipakai yakni observasi, wawancara, serta dokumentasi. Saat proses pengumpulan data menggunakan kisi-kisi untuk mempermudah pemetaan prosedur pengumpulan data yang digunakan.

\section{Analisis Data}

Tiga fase dalam proses analisis data yaitu reduksi data, penyajian data dan dikahiri dengan penarikan kesimpulan. Dalam proses reduksi data, data yang diperoleh akan disaring dan dilakukan pemilahan terhadap data penting. Sedangkan untuk data yang dianggap tidak dibutuhkan akan dibuang untuk mempermudah proses pengumpulan data selanjutnya. Setelah pengumpulan data dilakukan, dilakukan proses pengkodean sesuai dengan fokus penelitian. Pengkodean dalam analisis data ini dijabarkan dalam tabel 1 .

Table 1. Pengkodean analisis data

\begin{tabular}{lc}
\hline \multicolumn{1}{c}{ Aspek pengkodean } & Kode \\
\hline Fokus Penelitian & F1 \\
1. Rencana pembelajaran & F2 \\
2. Pelaksanaan pembelajaran & \\
Aspek yang diteliti & RP \\
1. Pengetahuan rencana pembelajaran & TM \\
2. Pengetahuan teori, model, strategi, dan metode pembelajaran & PP \\
3. Pengembangan rencana pembelajaran &
\end{tabular}


4. Implementasi rencana pembelajaran

Prosedur pengumpulan data

1. Wawancara

W

2. Observasi

O

3. Dokumentasi

D

Informan

1. Guru

G

2. Kepala sekolah

K

3. Siwa

S

Cara Membaca Kode (F1/RP/WG/01.01.2020)

Dibaca : Informasi tentang fokus penelitian rencana pembelajaran, diperoleh dari hasil wawancara guru, pada tanggal 01 januari 2020.

Fase kedua yakni penyajian data. Dalam fase ini, dilakukan pemaparan singkat yang berbentuk narasi dan gambar dokumentasi. Setelah fase kedua selesai, maka dilanjut dengan fase ketiga yakni penarikan kesimpulan. Proses penarikan kesimpulan diperoleh dari hasil penelitian dan analisis data dari penelitian di lapangan. Setelah penarikan kesimpulan dilakukan, maka dilakukanlah pengecekan ulang kesesuaian antara kesimpulan dengan data yang diperoleh dari lapangan.

\section{Pengecekan Keabsahan Data}

Teknik pemeriksaan data yang digunakan hanya berupa triangulasi data. Terdapat empat macam triangulasi yakni, 1) metode, 2) teori, 3) sumber data, dan 4) antar-peneliti (dilakukan ketika penelitian dilakukan kelompok). Penelitian ini hanya menggunakan dua macam triangulasi, yakni:

1. Triangulasi metode, dilakukan dengan menggali kebenaran sebuah informasi melalui berbagai metode dan sumber perolehan data. Triangulasi sumber dalam penelitian ini yakni membandingkan hasil wawancara dengan hasil pengamatan dan hasil dokumentasi.

2. Triangulasi sumber, dilakukan dengan cara membandingkan informasi atau jawaban dari berbagai narasumber. Peneliti memberikan pertanyaan yang sama kepada guru, kepala sekolah dan siswa. Hasil dari jawaban narasumber kemudian dibandingkan untuk dijadikan sebuah kesimpulan.

\section{HASIL}

\section{Rencana Pembelajaran}

Rencana pembelajaran merupakan perangkat pembelajaran berupa strategi yang digunakan guru untuk melaksanakan pembelajaran. penelitian ini menghasilkan data bahwa guru telah memiliki rencana pembelajaran secara lengkap. Guru memiliki rencana yang dikembangkan ketika masa liburan sekolah bersama kelompok kerja guru (KKG). Rencana pembelajaran ini yang kemudian disesuaikan keadaan di sekolah. Untuk menunjang pengetahuan guru mengenai Pedagogical Knowledge (PK), terdapat beberapa pelatihan ataupun seminar yang diadakan oleh dinas pendidikan maupun kelompok kerja guru (KKG). Terdapat beberapa pengetahuan yang harus dikuasai oleh guru sehubungan dengan pengembangan rencana pembelajaran, yaitu teori belajar, model, strategi dan metode pembelajaran.

Teori belajar merupakan sejumlah pandangan dari beberapa pakar tentang pembelajaran. Terdapat dua jenis teori belajar yang diketahui oleh guru yakni behavioristik dan konstruktivistik. Namun guru belum mampu menjelaskan perbedaan diantara kedua teori belajar tersebut. Selain teori belajar, guru juga diharuskan menciptakan pembelajaran yang bervariasi. Pembelajaran yang bervariasi ini dapat diciptakan jika guru menguasai model, strategi dan metode pembelajaran. Model, strategi, dan metode adalah hal yang berbeda namun terdapat keterkaitan dan memiliki tujuan yang sama, yakni mencari cara terbaik untuk mempermudah siswa mempelajari materi. Model pembelajaran itu sama halnya dengan metode pembelajaran, yaitu metode atau cara penyampaian guru kepada siswa. Sedangkan strategi itu langkah-langkah atau cara kita untuk mengajar agar pembelajaran berlangsung dengan baik. Contoh dari model pembelajaran yakni problem solving dan discovery learning. Sedangkan contoh metode pembelajaran yakni metode puisi, metode tanya jawab, metode klasikal, dan metode kelompok. Metode 
pembelajaran yang dipakai guru dalam rencana pembelajaran yakni permainan/simulasi, metode diskusi, metode tanya jawab, metode penugasan, dan metode ceramah.

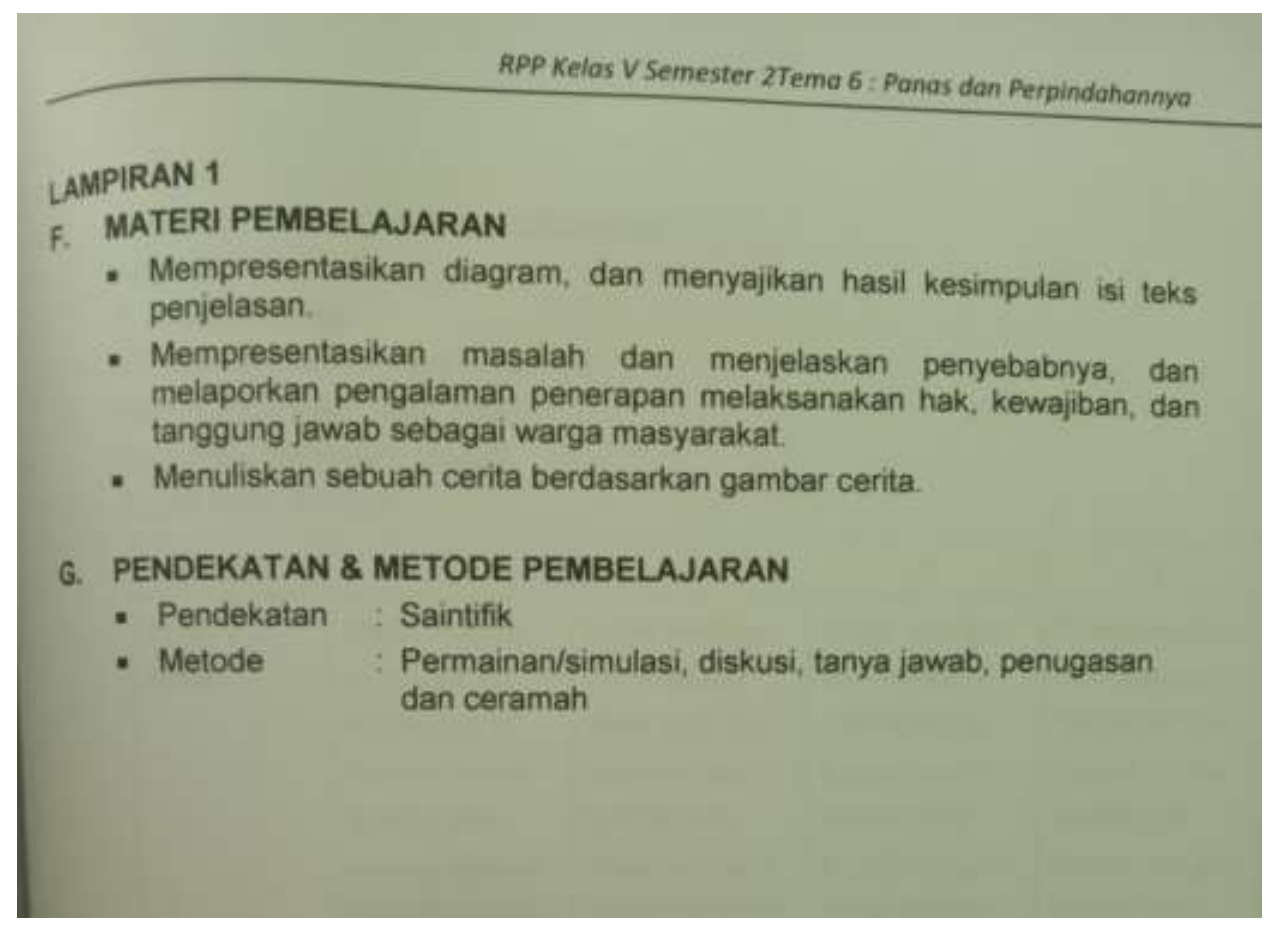

Gambar 2. Lampiran rencana pembelajaran

Acuan guru saat mengembangkan rencana pembelajaran yakni kurikulum. Proses pengembangan rencana pembelajaran dimulai dari melihat materi pembelajaran, kompetensi dasar, media yang tersedia di sekolah, serta memperhatikan kebutuhan siswa, gaya belajar, dan kemampuan awal siswa. Setelah itu menentukan indikator, tujuan pembelajaran, penyampaian materi, metode dan media jika dibutuhkan. Lalu membuat rencana pembelajaran dan menerapkannya. Berdasarkan hasil analisis, rat-rata gaya belajar yang dimiliki siswa yakni read dan auditori. Dalam rencana pembelajaran terdapat beberapa aspek yang harus dicantumkan, yakni identitas sekolah, kompetensi inti, kompetensi dasar, indikator, tujuan pembelajaran, sumber, media, serta metode pembelajaran. Saat mengembangkan rencana pembelajaran, terdapat beberapa kendala yang ditemui oleh guru yakni kurangnya waktu untuk mengembangkan dan ketidaksesuaian metode yang dipilih dengan siswa.

\section{Pelaksanaan Pembelajaran}

Dalam pelaksanaan pembelajaran, guru menggunakan rencana pembelajaran sebagai pedoman supaya tidak keluar dari pembelajaran yang telah direncanakan. Namun selalu ada improvisasi dari rencana pembelajaran yang telah dibuat. Hal ini terjadi karena dalam kenyataan biasanya ditemui kendala-kendala yang mengharuskan adanya perubahan. Hal ini pula yang menjadi kendala guru ketika mengembangkan rencana pembelajaran. 


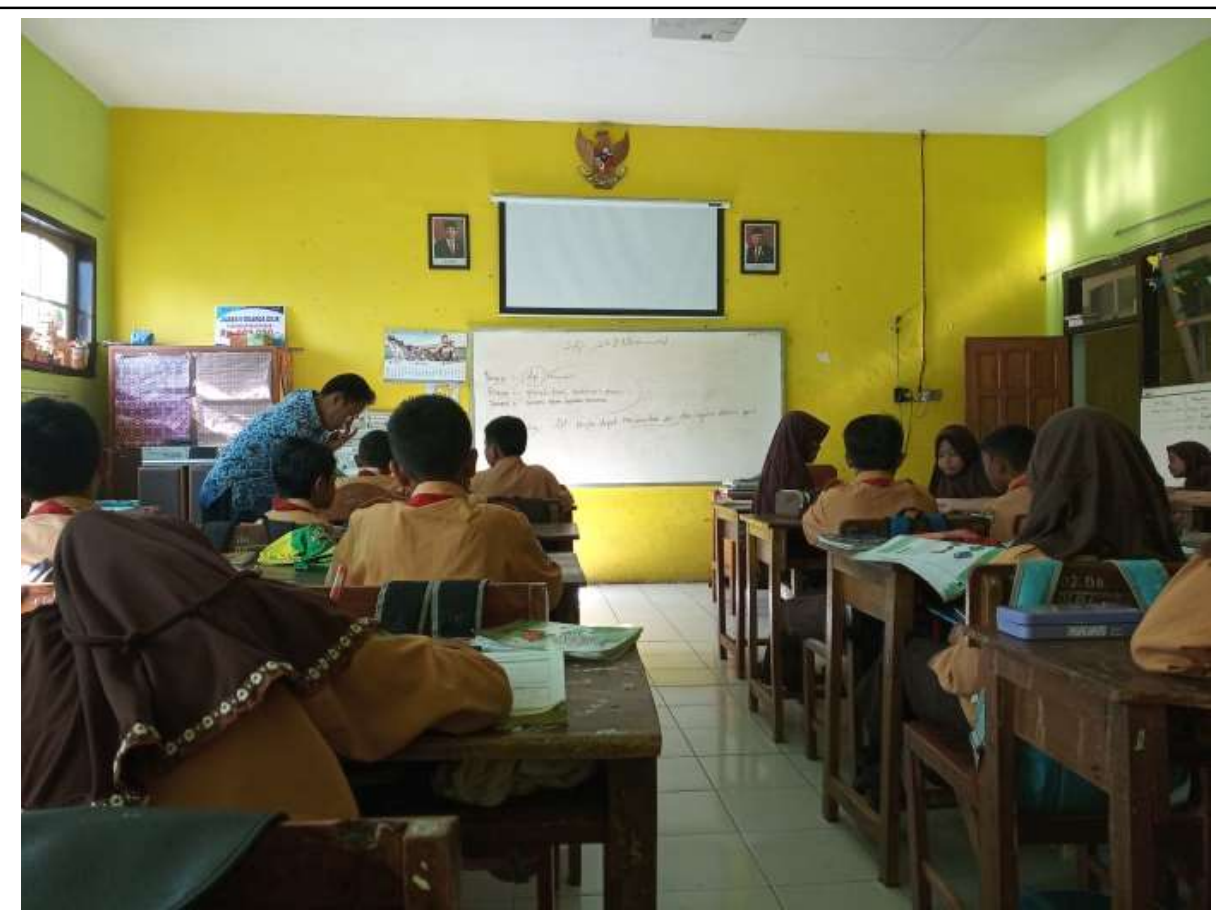

Gambar 3. Pembelajaran di kelas 5

Teori belajar yang digunakan guru saat pelaksanaan pembelajaran menyerupai teori belajar behavioristik. Selain itu, model pembelajaran yang diterapkan guru menyerupai model pembelajaran kooperatif. Strategi yang digunakan oleh guru menyerupai strategi discovery dan jigsaw. Serta metode pembelajaran yang sering digunakan oleh guru dalam pembelajaran menyerupai metode ceramah, pemberian tugas, tanya jawab, latihan dan terkadang menggunakan eksperimen dan diskusi.

Sebelum melakukan pembelajaran, guru selalu menggunakan apersepsi untuk membuat siswa tertarik dan siswa menjadi bersemangat saat belajar. Saat masuk ke pembelajaran, guru berusaha menyesuaikan pembelajaran dengan gaya belajar siswa yang lebih suka membaca dibandingkan mendengarkan ceramah dari guru. Hal ini dikarenakan siswa telah memiliki buku materi dan guru hanya memberikan tambahan saja. Namun ada juga siswa yang suka belajar melalui auditori. Untuk menunjang pembelajaran agar sesuai gaya belajar siswa, media pembelajaran yang diutamakan guru adalah media konkret, dan terkadang guru menggunakan media foto atau media video.

\section{PEMBAHASAN}

Sekolah Dasar Suburban telah menghasilkan siswa yang berprestasi, namun perolehan prestasi ini lebih dominan berasal dari prestasi non akademik. Untuk mencetak siswa berprestasi tidak terlepas dari pembelajaran yang direncanakan guru. Karena itulah, guru diharuskan mampu membuat rencana pembelajaran. Ini sesuai pernyataan (Schmidt et al., 2009) bahwa guru harus dapat menyusun pembelajaran yang membuat siswa belajar.

Rencana pembelajaran merupakan salah satu perangkat pembelajaran berupa strategi yang digunakan guru dalam rangka melaksanakan pembelajaran. (Kunandar, 2007) mengungkapkan bahwa rencana pembelajaran menggambarkan prosedur serta cara mengorganisir pembelajaran demi ketercapaian kompetensi dasar yang kemudian ditetapkan ke dalam standar isi kemudian dijabarkan menjadi silabus. Rencana pembelajaran ini digunakan guru agar pembelajaran berlangsung sesuai dengan tujuan pembelajaran.

Pengetahuan guru mengenai rencana pembelajaran telah sesuai teori (Joseph \& Leonard, 1988). Idealnya sebelum pembelajaran dimulai, guru harus memiliki rencana pembelajaran dan telah menyiapkannya. (Joseph \& Leonard, 1988) mengungkapkan bahwa mengajar tanpa persiapan tertulis akan menghasilkan ketidakefektifan pembelajaran di dalam kelas, hal ini terjadi karena guru tidak memikirkan secara detail apa yang akan dilakukan dan bagaimana melakukannya. Berdasarkan hasil penelitian, guru di sekolah dasar Suburban selalu menyiapkan rencana pembelajaran jauh-jauh hari sebelum dilaksanakannya pembelajaran, yakni saat liburan sekolah berlangsung. Itu artinya rencan 
pembelajaran yang dimiliki oleh guru lengkap. Pembuatan rencana pembelajaran ini dilakukan oleh guru bersama dengan guru-guru lain yang tergabung dalam Kelompok Kerja Guru (KKG).

Kelompok Kerja Guru (KKG) merupakan perkumpulan guru yang memiliki bidang mengajar sama dalam satu kecamatan. Kegiatan yang diadakan oleh KKG salah satunya adalah pelatihan/seminar untuk menunjang Pedagogical Knowledge (PK) guru. Pelatihan/seminar terkait pedagogi guru tidak hanya diadakan oleh KKG, namun terdapat instansi lain seperti dinas pendidikan yang memberikan pelatihan/seminar kepada guru.

Sebelum mengembangkan rencana pembelajaran, guru haruslah paham mengenai teori belajar, karena teori belajar menekankan terhadap bagaimana seharusnya seseorang belajar (Suyono, 2012). Hal ini sejalan dengan pemaparan (Mishra \& Koehler, 2006) bahwa Pedagogical Knowledge (PK) membutuhkan pemahaman tentang teori belajar. Teori belajar merupakan sejumlah pandangan dari beberapa pakar tentang pembelajaran.

Terdapat banyak teori belajar hingga saat ini, namun beberapa sumber telah mengelompokkannya menjadi 4 aliran yakni, behavioristik, konstruktivistik, kognitivistik dan humanistik. Dari hasil penelitian, diperoleh data bahwa guru mengetahui dua teori belajar, yakni teori belajar behavioristik dan konstruktivistik. Namun sangat diangkan, guru hanya bisa meyebutkan dua jenis teori belajar tanpa bisa menjelaskan apa yang dimaksud dengan behavioristik dan konstruktivistik serta bagaimana menerapkannya ke dalam pembelajaran.

Selain teori belajar, salah satu kemampuan yang seharusnya dimiliki guru sebagai tanda bahwa guru menguasai Pedagogical Knowledge (PK) menurut (Chai et al., 2010) yakni guru bisa menggunakan berbagai pendekatan pengajaran di ruang kelas (pengajaran kolaboratif, instruksi langsung, pembelajaran inkuiri, dll). Pendekatan yang dimaksud yakni model pembelajaran. Namun selain model pembelajaran, guru juga harus menguasai strategi serta metode pembelajaran. Menurut (Joyce \& Weil, 1980), model pembelajaran sejenis dengan rencana atau pola yang bisa dipakai untuk menentukan kurikulum pengajaran, memilih materi pelajaran, serta membimbing kegiatan guru. Sedangkan menurut (Sanjaya, 2014), strategi pembelajaran lebih merujuk pada sebuah perencanaan untuk mencapai sesuatu. Jika strategi pembelajaran merujuk pada perencanaan, maka metode pembelajaran merupakan cara yang digunakan untuk mencapai strategi.

Guru menyatakan bahwa model, strategi dan metode pembelajaran merupakan hal yang berbeda, namun memiliki keterkaitan dan memiliki tujuan yang sama yakni mencari cara terbaik agar mempermudah siswa mempelajari materi. Tapi disisi lain guru menjelaskan bahwa model pembelajaran itu sama halnya dengan metode pembelajaran, yaitu metode atau cara penyampaian guru kepada siswa. Sedangkan strategi itu langkah-langkah atau cara kita untuk mengajar agar pembelajaran berlangsung dengan baik. Guru mengetahui dua contoh model pembelajaran, yaitu problem solving dan discovery learning, serta empat metode pembelajaran yakni puisi, tanya jawab, klasikal, dan kelompok. Dalam rencana pembelajaran, metode yang sering dipakai guru yakni permainan/simulasi, diskusi, tanya jawab, pengasan, dan ceramah. Dari hasil penelitian, didapatkan data bahwa sebenarnya guru masih belum bisa membedakan antara model, strategi dan metode pembelajaran. Serta pengetahuan guru mengenai ketiga hal ini masih kurang.

Pengetahun guru mengenai teori-teori dalam desain pembeajaran masih kurang. Kekurangan ini berupa teori belajar, model pembelajaran, strategi pembelajaran, dan metode pembelajaran. Namun dalam pelaksanaannya guru sudah dapat menentukan teori, model, strategi, metode yang cocok digunakan dalam pembelajaran, walaupun guru belum sepenuhnya mengetahui nama dari teori, model, strategi, metode yang digunakan.

Pengembangan rencana pembelajaran guru belum sesuai dengan pengembangan desain pembelajaran ADDIE. Menurut (Branch, 2009), terdapat lima tahapan pengembangan model ADDIE yakni Analysis (analisa), dilanjutkan dengan Design (desain/perancangan), kemudian Development (pengembangan), lalu Implementation (implementasi/eksekusi), dan terakhir adalah Evaluation (evaluasi/umpan balik). Berdasarkan hasil penelitian, langkah-langkah pengembangan rencana pembelajaran yang dilakukan oleh guru dimulai dengan analisis, dilanjutkan dengan desain, pengembangan dan diakhiri implementasi. Tahapan evaluasi guru hanya berupa keinginan, guru belum melakukan evaluasi hanya melakukan assessment atau penilaian mengenai hasil belajar siswa. Evaluasi bertujuan untuk menganalisis serta melakukan perbaikan terhadap kesalahan yang terjadi selama proses pembelajaran. 
Proses pengembangan rencana pembelajaran dimulai dari melihat materi pembelajaran, kompetensi dasar, media yang ada di sekolah, serta memperhatikan kebutuhan siswa, gaya belajar, dan kemampuan awal siswa. Setelah itu menentukan indikator, tujuan pembelajaran, penyampaian materi, metode dan media jika dibutuhkan. Lalu membuat rencana pembelajaran dan menerapkannya. (Schmidt et al., 2009) menyatakan bahwa guru harus tahu bagaimana siswa belajar. Oleh sebab itu, guru diharuskan mengetahui gaya belajar yang dimilki oleh siswanya. Berdasarkan analisis guru, sebagian besar siswanya mempunyai gaya belajar read dan audiotori.

Terdapat beberapa aspek penting yang perlu ada dalam setiap rencana pembelajaran yakni, identitas sekolah, kompetensi inti, kompetensi dasar, indikator, tujuan pembelajaran, sumber, media, metode pembelajaran. Kelengkapan aspek ini berguna untuk memperjelas isi dari rencana pembelajaran yang telah dibuat guru. Saat mengembangkan rencana pembelajaran, terdapat beberapa kendala yang ditemui oleh guru yakni kurangnya waktu untuk mengembangkan dan ketidaksesuaian metode yang dipilih dengan siswa. Kendala dalam mengembangkan rencana pembelajaran ini pasti akan mempengaruhi pelaksanaan pembelajaran.

Pengimplementasian rencana pembelajaran guru telah sesuai dengan teori (Chai et al., 2010) dan (Schmidt et al., 2009). Saat pembelajaran, guru menggunakan rencana pembelajaran sebagai pedoman untuk menghindari ketidaksesuaian antara proses pembelajaran dengan tujuan yang ingin dicapai. Namun saat implementasi biasanya terdapat perbedaan antara pelaksanaan dengan rencana yang dibuat guru. Terjadinya improvisasi dikarenakan guru menyesuaikan kebutuhan siswa saat proses pembelajaran berlangsung. Improvisasi dalam pembelajaran memang wajar terjadi, (Chai et al., 2010) mengungkapkan bahwa guru harus bisa menyesuaikan pengajaran berdasarkan apa yang dipahami dan tidak dipahami siswa. Hal ini tidak menjadi masalah besar, asalkan masih sesuai dengan tujuan pembelajaran yang telah ditentukan. Guru sudah bisa menyesuaikan pengajaran berdasarkan apa yang dipahami dan tidak dipahami siswa, melalui improvisasi rencana pembelajaran untuk menyesuaikan kebutuhan siswa.

Saat proses pembelajaran, seorang guru harus tahu pendekatan pembelajaran yang mana yang cocok untuk diterapkan di kelas (Schmidt et al., 2009). Teori belajar yang digunakan guru saat pembelajaran menyerupai teori belajar behavioristik. Strategi yang digunakan oleh guru menyerupai strategi discovery dan jigsaw. Untuk mencapai strategi pembelajaran, guru menggunakan beberapa metode pembelajaran. Metode pembelajaran yang sering digunakan oleh guru dalam pembelajaran menyerupai metode ceramah, pemberian tugas, tanya jawab, latihan dan terkadang menggunakan eksperimen dan diskusi. Guru tidak pernah menggunakan metode permainan/simulasi seperti yang dicantumkan di dalam rencana pembelajaran. Guru telah mengetahui pendekatan pembelajaran yang apa yang cocok diterapkan di kelas, walaupun pengetahuan mengenai teorinya masih kurang.

Ketika proses pembelajaran berlangsung, guru harus bisa menyesuaikan gaya mengajar dengan pelajar yang berbeda (Chai et al., 2010). Ini disebabkan oleh beragamnya karakteristik pelajar dalam sebuah kelas. Karena itu, guru harus menciptakan pembelajaran yang menarik perhatian siswa agar siswa merasa ingin belajar tanpa merasa terpaksa. Berdasarkan hasil penelitian, guru membuka pembelajaran dengan apersepsi. Apersepsi digunakan oleh guru agar siswa dapat fokus terhadap pembelajaran yang disampaikan. Setelah itu, materi pembelajaran disampaikan dan disesuaikan dengan gaya belajar siswa. Guru sering menggunakan media konkret, dan terkadang guru menggunakan foto atau video karena merasa media tersebut yang cocok dengan gaya belajar siswa. Guru sudah bisa menyesuaikan gaya mengajar dengan pelajar yang berbeda, dengan cara menyesuaikan pembelajaran dengan gaya belajar siswa dan karakter siswa.

\section{SIMPULAN}

Rencana pembelajaran merupakan perangkat pembelajaran berupa strategi yang digunakan guru dalam rangka melaksanakan pembelajaran. Rencana pembelajaran yang dimiliki guru Sekolah Dasar Suburban telah lengkap, dengan kata lain guru selalu memiliki rencana pembelajaran sebelum melakukan pembelajaran. Untuk menunjang Pedagogical Knowledge (PK) guru, diadakan sebuah pelatihan atau seminar oleh Dinas Pendidikan, KKG atau instansi lainnya.

Pengetahun guru mengenai teori-teori dalam desain pembelajaran masih kurang. Pengembangan rencana pembelajaran guru belum sesuai desain pembelajaran ADDIE. Tahapan analisis, desain, pengembangan, dan implementasi telah dilaksanakan. Sedangkan pada tahap evaluation 
(evaluasi/umpan balik) hanya berupa keinginan. Dalam kenyataannya guru hanya melakukan assessment atau penilaian terhadap hasil belajar siswa.

Pengimplementasian rencana pembelajaran guru sesuai dengan teori (Chai et al., 2010) dan (Schmidt et al., 2009). Guru sudah bisa menyesuaikan pengajaran berdasarkan apa yang dipahami dan tidak dipahami siswa. Guru sudah mengetahui pendekatan pembelajaran yang mana yang cocok untuk diterapkan di kelas. Guru sudah bisa menyesuaikan gaya mengajar dengan pelajar yang berbeda.

Terdapat beberapa saran bagi guru berdasarkan hasil penelitian ini. Guru harus mempelajari lebih dalam mengenai teori-teori dalam desain pembelajaran. Teori-teori ini berupa teori belajar, model pembelajaran, strategi dan metode pembelajaran. Hal ini disarankan agar guru dapat merencanakan pembelajaran yang bervariasi dan memiliki acuan lebih banyak dalam proses perencanaan. Sehingga pembelajaran terlaksana sesuai teori yang telah dipelajari. Selain itu, guru juga perlu mempelajari bagaimana mengembangkan pembelajaran secara lengkap sesuai dengan tahapan dalam desain pembelajaran ADDIE. Guru harus lebih mengerti gaya belajar dan karakteristik siswanya. Pedagogical Knowledge (PK) guru dapat ditingkatkan melalui keikutsertaan guru dalam berbagai pelatihan dan pemantauan terhadap hasil pelatihan.

Bagi peneliti yang akan melakukan penelitian mengenai Technological Pedagogical and Content Knowledge (TPACK), diharapkan dapat melakukan penelitian yang berhubungan dengan teknologi. Karena di abad 21 proses pembelajaran sudah tidak bisa dipisahkan dengan penggunaan teknologi. Selain itu, penelitian mengenai teknologi akan tetap menjadi topik yang terus berkembang.

\section{DAFTAR RUJUKAN}

Archambault, L., \& Crippen, K. (2009). Examining TPACK among K-12 online distance educators in the United States. Contemporary Issues in Technology and Teacher Education, 9(1), 71-88.

Arends, R. I. (2008). Learning to teach: belajar untuk mengajar. Yogyakarta: Pustaka Pelajar.

Bararah, I. (2017). Efektifitas Perencanaan Pembelajaran dalam Pembelajaran Pendidikan Agama Islam di Sekolah. Jurnal MUDARRISUNA: Media Kajian Pendidikan Agama Islam, 7(1), 131-147.

Branch, R. M. (2009). Instructional design: The ADDIE approach (Vol. 722). Springer Science \& Business Media.

Chai, C. S., Koh, J. H. L., \& Tsai, C.-C. (2010). Facilitating Preservice Teachers' Development Of Technological, Pedagogical, And Content Knowledge (TPACK). Journal of Educational Technology \& Society, 13(4), 6373.

Cox, S., \& Graham, C. R. (2009). Using an elaborated model of the TPACK framework to analyze and depict teacher knowledge. TechTrends, 53(5), 60-69.

Feladi, V., \& Puspitasari, H. (n.d.). Analisis Profil TPACK Guru TIK SMA di Kecamatan Pontianak Kota. Jurnal Edukasi Dan Penelitian Informatika (JEPIN), 4(2), 205-213.

Hidayati, N., Setyosari, P., \& Soepriyanto, Y. (2019). Kompetensi Technological Pedagogical Content Knowledge (TPACK) Guru SOSHUM Setingkat SMA. Jurnal Kajian Teknologi Pendidikan, 1(4), 291-298.

Iftitah, K. N. (2017). Profil Technological, Pedagogical, Content Knowledge (TPACK) Guru Ilmu Pengetahuan Alam (IPA) Pada Jenjang Sekolah Menengah Pertama (SMP). SKRIPSI Jurusan Teknologi PendidikanFakultas Ilmu Pendidikan UM.

Joseph, C. F., \& Leonard, C. H. (1988). Teaching in the middle and secondary schools 3rd. New York: macmillan. Joyce, B., \& Weil, M. (1980). Models of teaching (2aed.). Englewoods Ce Hall.

Kalu, M. R. (2016). Kompetensi Pedagogik Dan Profesional Guru Sekolah Dasar Yang Tersertifikasi Pada Pembelajaran Sains. JSTT, 5(3).

Koehler, M., \& Mishra, P. (2009). What Is Technological Pedagogical Content Knowledge (TPACK)? Contemporary Issues in Technology and Teacher Education, 9(1), 60-70.

Kunandar. (2007). Guru profesional: Implementasi Kurikulum Tingkat Satuan Pendidikan (KTSP) Dan Persiapan Menghadapi Sertifikasi Guru. Divisi Buku Perguruan Tinggi, Raja Grafindo Persada.

Mishra, P., \& Koehler, M. J. (2006). Technological Pedagogical Content Knowledge: A framework For Teacher Knowledge. Teachers College Record, 108(6), 1017-1054.

Rachmatulloh, C. K., Fitriah, E., \& Lestari, R. (2015). Analisis Penerapan Target Costing untuk Meningkatkan Laba Perusahaan (Studi Kasus pada CV. Onderhoud Company Shoes and Leather).

Sanjaya, W. (2014). Penelitian Pendidikan: Jenis. Metode Dan Prosedur, Jakarta: Kencana.

Schmidt, D. A., Baran, E., Thompson, A. D., Mishra, P., Koehler, M. J., \& Shin, T. S. (2009). Technological Pedagogical Content Knowledge (TPACK) The Development And Validation Of An Assessment Instrument For Preservice Teachers. Journal of Research on Technology in Education, 42(2), 123-149.

Shulman, L. S. (1987). Shulman, Lee S.," Knowledge and Teaching: Foundations of the New Reform," Harvard Educational Review, 57 (February, 1987), 1-22.

Sintawati, M., \& Indriani, F. (2019). Pentingnya Technological Pedagogical Content Knowledge (TPACK) Guru 
Di Era Revolusi Industri 4.0. Prosiding Seminar Nasional Pagelaran Pendidikan Dasar Nasional (PPDN) 2019, 1(1), 417-422.

Sudjana, N. (2004). Penelitian Hasil Proses Belajar. Penerbit PT Remaja Rosdakarya, Bandung.

Suharwoto, G., \& Niess, M. (2001). How Do Subject Specific Teacher Preparation Program That Integrate Technology Throughout The Courses Support The Development Of Mathematics Preservice Teachers' TPCK (Technology Pedagogical Content Knowledge). Retrieved June, 12, 2008.

Sumiarsi, N. (2015). Analisis Kompetensi Pedagogik Dan Pengembangan Pembelajaran Guru SD Negeri 041 Tarakan. Jurnal Kebijakan Dan Pengembangan Pendidikan, 3(1).

Suyono, H. (2012). Belajar Dan Pembelajara. Bandung: Remaja Rosdakarya.

Zendrato, J. (2016). Tingkat Penerapan Rencana Pelaksanaan Pembelajaran dalam Pelaksanaan Pembelajaran di Kelas Suatu Studi Kasus di SMA Dian Harapan Jakarta. Scholaria: Jurnal Pendidikan Dan Kebudayaan, $6(2), 58-73$. 